\title{
ナノマテリアルの細胞内動態と遺伝毒性
}

\author{
阿 部 康 弘
}

\section{Safety Studies of Nanomaterials about Intracellular Distribution and Genotoxicity}

\author{
Yasuhiro ABE \\ Laboratory of Biopharmaceutical Research, National Institute of Biomedical Innovation, \\ 7-6-8 Saito-Asagi, Ibaraki, Osaka 567-0085, Japan
}

(Received September 3, 2010)

\begin{abstract}
Recently, nanomaterials (NMs) showing useful properties such as controlled release and tissue permeability have been developed for practical use as medicine and cosmetics. On the other hand, because NMs possess innovative properties, kinetics, and biological effects distinct from those of micro size bulk materials, the potential harmful effects of NMs on humans are raising concerns about their safety. Therefore, there is an urgent need for risk assessment of NMs. To achieve this, it is most important to analyze the relationship between physicochemical properties such as particle size and surface characteristics, cellular distribution and biological effects, allowing prediction and avoidance of risk in using NMs. However there is little information about association of nanomaterial properties with kinetics (exposure, absorption, distribution, and excretion). In this respect, we have not only collected hazard information on NMs but have also analyzed the linkage between silica particle size and their hazards. We have demonstrated that NM with a diameter of under $100 \mathrm{~nm}$ can penetrate the stratum corneum of mouse skin and are taken up by living cells such as keratinocytes and Langerhans cells. Additionally, NM taken up by cells entered the nucleus, indicating the risk of genotoxicity. In this review, we would like to discuss the relationship between particle size, intracellular distribution, and hazard effect.
\end{abstract}

Key words_— nanomaterial; NanoSafety; nanosilica; safety science

\section{1. はじめに}

近年，わが国においては，徐放能や組織浸透・拡 散能といつた有用機能を発揮するナノマテリアルの 開発と，これらの医薬品・食品・化粧品への導入・ 実用化が進展している。一方で欧米各国では，この ようなナノマテリアル特有の物性に起因する革新的 機能が逆に，ヒトの健康環境に負の影響（ナノ毒 性；NanoTox）を及ぼす可能性を懸念し, ナノマ テリアルの安全性評価（NanoSafety 評価）にも力 を注ぎ始めている. 1,2) 事実, 粒径 $100 \mathrm{~nm}$ 以下のナ ノマテリアルが従来までのサブミクロンサイズ以上 の素材（凝集体としてサブミクロンサイズ以上にな るナノマテリアルを含む）とは異なつた体内吸収性 や体内動態を示すことが，少しずつ判明してきてい

独立行政法人医薬基盤研究所バイオ創薬プロジェクト （干567-0085 大阪府茨木市彩都あさぎ 7-6-8)

e-mail: yasuhiro@nibio.go.jp

本総説は, 日本薬学会 130 年会シンポジウム S18 で発 表したものを中心に記述したものである.
る、例えば，筆者らの研究グループの検討において も, 直径が $70 \mathrm{~nm}$ の非晶質ナノシリカを皮膚に曝 露させた場合，角質バリアを通過して体内に吸収さ れ得ることを見い出している。同時に，直径が 300 $\mathrm{nm}, 1000 \mathrm{~nm}$ の非晶質シリカは皮膚角質バリアを通 過しないことを確認しており，これらの結果は，ナ ノシリカは $100 \mathrm{~nm}$ 程度以下のサイズになると初め て経皮吸収性を発揮するようになり，体内曝露につ ながり得ることを示している。ささらに体内に移行 し, 組織に分布したナノマテリアルは, 最終的に組 織細胞に取り込まれる可能性が考えられる。しか し, 細胞内での動態に着目したナノマテリアルの安 全性研究はほとんど報告されていない.

今やナノマテリアルは，化粧品材料や食品添加物 を始めとして，既にわれわれヒトに直接適用される 製品に使用されている。これらは，年龄や疾患の有 無を問わず，あらゆるヒトが一生涯に渡つて使用・ 摂取し続けるものであることから，たとえわずかな 量であっても，長期に渡って曝露することによって 
健康に問題が生じる可能性が危惧される。そのた め，ナノマテリアルの使用が増加しつつある今こ そ,ナノマテリアルの詳細な安全性評価及び安全性 確保に向けた取り組みが必要である。しかしなが ら，ナノマテリアルの安全性研究においては，いま だハザード情報が散在するばかりで，安全性評価指 針の策定や安全なナノマテリアルの設計指針につな がる情報の抽出には至っておらず，特にナノマテリ アルの細胞内動態やオルガネラ蓄積性に関する情報 は，ハザード情報ですら圧倒的に不足しているのが 現状である。したがって，ヒトの健康環境を確保し つつナノマテリアルの恩恵を最大限に享受した豊か な社会を実現するためには，まずナノマテリアルと 従来までのサブミクロンサイズ以上の素材との体内 /細胞内動態や生体/細胞への影響における相違点を 科学的根拠に基づいて明らかにすることが急務であ り，それらの情報を基盤として，より具体的な安全 性評価法を確立することが重要である．以上の観点 から筆者らは，種々のナノマテリアルの中でも，生 産量・使用量・用途の点で，最もわれわれの生活に 浸透している非晶質ナノシリカをモデルナノマテリ アルとして，素材の物性（サイズ，表面電荷，親/ 疎水バランス，形状など） が体内/細胞内動態や生 体/細胞応答に与える影響の解析を進めている。こ れらナノマテリアルの物性-動態一安全性の連関情報 を集積し，ナノマテリアルと従来の素材との違いを 明確化するとともに，それらの因果関係を精査する ことによって, 最終的にナノマテリアルの動態情報 から安全性を評価する方法の確立，及び安全なナノ マテリアルの開発と実用化の支援の実現につながる ものと考えている，そこで本稿では，非晶質ナノシ リカが多くの香粧品に既に使用されているという現 状を踏まえて，皮膚細胞への影響を中心に検討を進 め，特に，様々なサイズの非晶質シリカについて， 細胞内動態や細胞への影響を解析した結果を紹介し たい.

\section{2. 非晶質ナノシリカの体内動態の評価}

非晶質ナノシリカの用途は非常に幅広く，日焼け 止めやファンデーションなどの化粧品基材，歯磨き 粉や歯の充填剤，さらには食品の固結防止剤として 利用されている. ${ }^{3)}$ また，ナノシリカは食品中に最 大 $2 \%$ ，化粧品におおよそ $20 \%$ 程度が配合されてい る. 従来までのサブミクロンサイズ以上のシリカに
ついての安全性評価は 2006 年の欧州化学物質生態 毒性・毒性センターにより実施された。 ${ }^{4)}$ その結 果，サブミクロンサイズ以上のシリカ（凝集体とし てサブミクロンサイズ以上になるナノシリカを含 む）の安全性に問題はないと報告されている。しか し，筆者らは分散性の高い直径 $70 \mathrm{~nm}$ の非晶質ナ ノシリカが皮膚バリアを通過し肝臓にまで移行する 可能性を示している（角田らの稿を参照）。したが って，細胞の大きさよりも小さな $100 \mathrm{~nm}$ 以下の非 晶質ナノシリカが組織に曝露した際には, 細胞内小 器官といった深部にまで到達してしまうことが危惧 される，細胞膜におけるデスレセプターの活性化や 核における DNA の損傷などは，多くの細胞にアポ トーシスを誘導することが知られているが，さらに 近年，小胞体やミトコンドリアなど他の細胞内小器 官での障害を発端としたストレス応答がアポトーシ スの誘導につながり得ることが明らかとなりつつあ る.5）そのため，香粧品素材として既に赛用化され ている非晶質ナノシリカをモデル粒子として用い, 直径 $100 \mathrm{~nm}$ 以下のナノシリカの細胞内における詳 細な動態情報を収集し, 細胞応答に与える影響との 連関解析を進めることは急務であると言える。

そこで本研究ではまず，ヒト皮膚角化細胞株 （HaCaT 細胞）を用いて，粒子サイズが異なる非晶 質シリカの細胞内動態一細胞影響に与える影響につ いて検証を行った．粒子径が $70 \mathrm{~nm}(\mathrm{nSP} 70)$ のナ ノシリカ，その対照として $300 \mathrm{~nm}(\mathrm{nSP} 300), 1000$ $\mathrm{nm}(\mathrm{mSP} 1000)$ のサブミクロンサイズ以上の従来 型シリカをそれぞれ $\mathrm{HaCaT}$ 細胞と 24 時間共培養 し，その増殖性を $\left[{ }^{3} \mathrm{H}\right]$ チミジンの取り込みを指 標に検証した [Fig. 1(A)]。その結果，いずれの粒 子を作用させた場合においても粒子濃度依存的な細 胞増殖抑制効果が認められ，その効果は nSP70 添 加群で最も強いことが判明した。 さらに，ナノシリ カの細胞膜に対する傷害性を Lactate dehydrogenase (LDH) release assay により評価したところ, 細胞 増殖試験のデータと相関して，粒子サイズの減少に 伴い，細胞膜に対する傷害性が増大する傾向が認め られた [Fig. 1(B)]。これらの結果から，非晶質ナ ノシリカとサブミクロンサイズ以上の従来型シリカ とでは異なる細胞膜傷害性を示すこと，つまり粒子 サイズが細胞に対する作用に大きく影響することが 示された。続いて，非晶質シリカの粒子サイズが細 
A

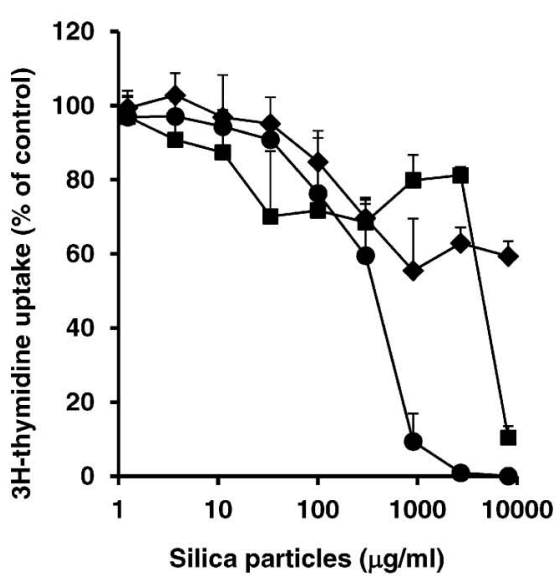

B

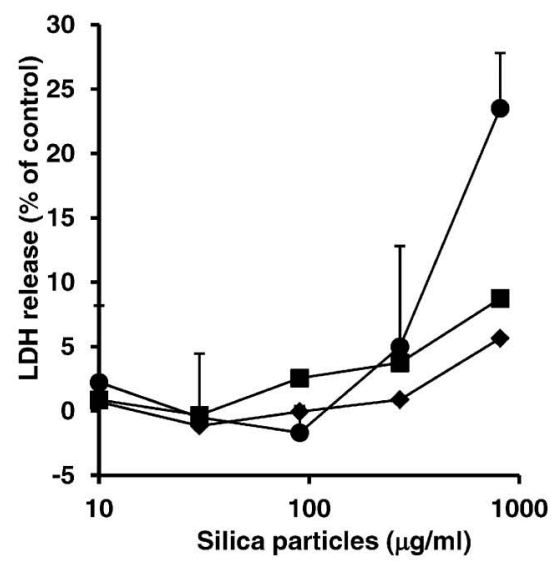

Fig. 1. Effect of Various Sized Silica Particles on Cell Proliferation

A) Proliferation of $\mathrm{HaCaT}$ cells following $24 \mathrm{~h}$ of incubation with the indicated concentrations of nSP70 (circles), nSP300 (squares) and mSP1000 (diamonds) were measured using the tritium thymidine uptake assay. B) Cellular membrane damage in HaCaT cells after incubation with nSP70 (circles), nSP300 (squares) and mSP1000 (diamonds) for $24 \mathrm{~h}$ was evaluated by the LDH release assay. The percentage cellular membrane damage was calculated relative to the negative (medium) controls. Each data point represents mean \pm S.D. $(n=3)$.

胞反応性に影響を与える機構の解明を目指して，各 粒子の細胞内局在を解析した。 $100 \mu \mathrm{g} / \mathrm{ml}$ に調製し た nSP70, nSP300, 及び mSP1000 のシリカを $\mathrm{HaCaT}$ 細胞に添加した後, 24 時間後に透過型電子 顕微鏡を用いて in vitroにおける細胞内取り込み, 及び細胞内局在の解析を行つた。 その結果，従来型 シリカである nSP300 あるいは mSP1000 を適用し たいずれの群においても，各シリカが細胞内に侵入 した像が認められた。また， mSP1000 添加群にお いては細胞内に侵入した粒子の周辺にリソソーム様 小胞が過唾に形成する像が認められた。 それに対し て，nSP70は，細胞内に侵入するだけでなく，そ の一部は核膜を通過して核内にまで侵入していた. さらに興味深いことに，核内に到達した nSP70 の 大部分が核小体に集積している像が認められた。以 上の結果より，非晶質シリカは，粒子径の違いによ ってその細胞内局在が大きく変動することが明らか となった．特に，nSP70が核内にまで移行すると いう特徵的な細胞内動態を示すことを加味すると, 核機能や遺伝子に着目した安全性評価を行うことが 必要であることが示された。

\section{3. 非晶質シリカの変異原性試験及び遺伝子に与}

\section{える影響の解析}

細胞の核は, DNA や RNA の合成・保存の場で あり，遺伝子の発現を調節することで細胞の恒常性 を維持していることから，nSP70 が細胞に対して 重大な影響を及ぼしてしまうことが懸念される。一
般的に，遺伝子に影響を及ぼす作用を有する物質 （変異原）は, $N$-methyl- $N^{\prime}$-nitro- $N$-nitrosoguanidine （MNNG）などの DNA にアルキル基を付加するア ルキル化剂, ${ }^{6}$ 抗がん剂のシスプラチンなど DNA 分子中の 2 個の塩基に結合し架橋構造を作る DNA 架橋剂など DNA に直接作用するものや, 7) 放射線 のように細胞内に活性酸素種を引き起こし作用する ものが挙げられる。nSP70が細胞の核内にまで移 行するという事実は，nSP70 が上記の変異原物質 と同様に遺伝子に対して直接的あるいは間接的にな んらかの影響を及ぼす可能性が高いことを示唆して いる，そこで次に，このような動態情報を踏まえ て, 非晶質シリカの変異原性及び $\mathrm{HaCaT}$ 細胞の遺 伝子に与える影響について検証した。まず，粒子径 の異なる非晶質シリカの変異原性を検証するために,

Ames 試験を行った．本検討では，塩基置換型突然 変異を検出する TA100 株とフレームシフト型突然 変異を検出する TA98 株の 2 菌株を用いて試験を行 い, DMSO 添加群よりも 2 倍以上のコロニー増加 が認められた群を陽性と判断した。その結果,

TA98 株では，いずれのシリカを添加した群でも変 異コロニーの出現は全く認められなかったのに対し て，TA100 株では，粒子径が小さくなるほど，変 異コロニー数の増加が認められた。これらの結果は Ames 試験において非晶質ナノシリカが塩基置換型 突然変異を誘発することを示唆するものである. Ames 試験で陽性となった化合物でも発がん性試験 
を行った際に陰性となる例も多く報告されているこ とから ${ }^{8)}$ この結果がかならずしも発がん性につな がるとは言えないが，これらの結果は，少なくとも 非晶質シリカの粒子サイズが変異原性に影響を与え 得ること,ナノマテリアルの安全性を解析するに当 たつては凝集性などを考慮した物性情報の収集が不 可欠であることを裏付けるものである.

続いて，コメットアッセイにより非晶質シリカの $\mathrm{HaCaT}$ 細胞における DNA 損傷性を評価した。 nSP70, nSP300, mSP1000を 30, $90 \mu \mathrm{g} / \mathrm{ml}$ の濃度で 添加し, 3 時間後に Tail length の值を指標に評価し たところ，nSP300 と mSP1000を添加した群では DNA 損傷は全く検出されなかった。一方，nSP70 添加群においては，陽性コントロールとして使用し た過酸化水素添加群に匹敵するほどの DNA 損傷性 の増大が認められた。この結果は，100 nm 以下の サイズの nSP70 のみが HaCaT 細胞に対して DNA 損傷を引き起こすことを示すものである. そこで次 に，非晶質ナノシリカの安全性確保を目指して, ROS 産生の観点から HaCaT 細胞の DNA 損傷の発 現メカニズムの解明を試みた。まず， $\mathrm{HaCaT}$ 細胞 を用いて非晶質シリカ処理による ROS 産生の有無 を検証した。 nSP70, nSP300, mSP1000を HaCaT 細胞に添加して 3 時間後の細胞内における ROS 量 をDCFH-DA の蛍光量を指標に測定した。その結 果，すべてのサイズの非晶質シリカを添加した群に おいて ROS の産生が認められたが，特に nSP70 添 加群において最も顕著な ROS 産生が認められた。 コメットアッセイで用いたシリカと同じ濃度で, ROS 産生が起こっていることが確認されたことか ら，直径が $100 \mathrm{~nm}$ 以下になると ROS 依存的な DNA 損傷作用を発揮する可能性が考えられる。 そ こで，nSP70による ROS 産生と DNA 損傷発現メ カニズムとの関連について精査するために，抗酸化 剂である $N$-アセチルシステイン (NAC) 存在下に おける nSP70 の DNA 損傷作用を評価した。 NAC を前処理した $\mathrm{HaCaT}$ 細胞に対して，30 分後に nSP70 を添加し，コメットアッセイを行った。粒 子添加 3 時間後に ROS 産生量を定量したところ, NAC を前処理した群では, PBS 添加群と同等の值 にまで Tail Lengthの值の減少が認められた。抗酸 化剂共存下で nSP70 依存的 DNA 損傷作用の抑制 が認められたことから，nSP70 による DNA 損傷が
ROS を介して生ずることが裏付けられた。これま でにも，フラーレンを用いた検討により ROS が細 胞傷害性に関与する例や，酸化チタンが産生する ROS が p53 発現を誘導し最終的に DNA 損傷に関 与する例が報告されており，これらの結果からも， nSP70 による DNA 損傷発現メカニズムには ROS が強く関与していることが示唆された。すなわち， nSP70 の ROS 産生や細胞内局在を制御すること で，安全なナノマテリアルの創製が実現するものと 考えられた。

\section{4. おわりに}

本研究では，最もわれわれの生活に浸透している 非晶質ナノシリカの粒子サイズが細胞内動態-細胞 応答に与える影響について連関解析を行つた。 その 結果, $70 \mathrm{~nm}$ の非晶質ナノシリカはサブミクロンサ イズ以上の従来型シリカとは異なる細胞内局在・細 胞応答を示す可能性を示した。このことは，非晶質 ナノシリカの安全性評価を行う際には，第一に従来 型シリカとは別個の素材として捉え独自の安全性評 価を行う必要があることを裏付ける結果である。ま た，今回は DNA 損傷発現メカニズムに着目して解 析を進めたが，現在，さらなる安全性情報の収集に 向け，核内移行性という情報に基づいたプロテオミ クス解析により, ナノシリカの曝露によって発現変 動する核内タンパク質を多数見い出している。これ ら発現変動タンパク質と核機能との連関解析によっ て，さらに詳細な粒子サイズー細胞内動態-細胞応答 情報を収集し得るもの，と考えている，今後，この ような細胞内動態と安全性の連関解析を行うことに より，「細胞内動態を基盤とした非晶質ナノシリカ の安全性評価法」を確立できるものと期待している.

さらに将来的には，細胞内動態のみならず生体内 動態と安全性の連関解析を行うとともに，表面性 状，表面電荷との連関解析を行うことを計画してい る。事実，筆者らは，表面物性を改良することで, 非晶質ナノシリカによる DNA 損傷発現を抑制でき ることを見い出しており，この結果は表面物性が DNA 損傷発現メカニズムに与える影響を精査する ことにより，安全な非晶質ナノシリカの開発支援に つながる有用なアプローチであることを実証するも のである。このような, 物性-動態-生体影響の連関 解析を通じて，非晶質ナノシリカのみならず，あら ゆるナノマテリアルに応用可能な安全性評価法を確 
立し，安全設計指針の確立及びナノマテリアルの恩 恵を最大限に享受した豊かな社会の実現につながる ことを強く祈念している。

謝辞本研究は, 独立行政法人医薬基盤研究所 バイオ創薬プロジェクトリーダー角田慎一先生，同 サブリーダー鎌田春彦先生, 同プロジェクト研究員 長野一也先生を始めとする多くの先生方のご指導の 下，鍋師裕美先生，松山恵吾氏，仲里泰太郎氏，有 森亮裕氏，磯部将彰氏など，独立行政法人医薬基盤 研究所バイオ創薬プロジェクト・大阪大学薬学研究 科医薬基盤科学分野の皆さまとの共同成果であり,

この場をお借りして，御礼を申し上げます。また大 阪大学大学院薬学研究科特任助教鍋師裕美先生の御 協力に深謝申し上げます.

\section{REFERENCES}

1) Poland C. A., Duffin R., Kinloch I., Maynard
A., Wallace W. A., Seaton A., Stone V., Brown S., Macnee W., Donaldson K., Nat. Nanotechnol., 3, 423-428 (2008).

2) Webster T. J., Int. J. Nanomedicine, 3(2) , i-ii (2008).

3) Merget R., Bauer T., Kupper H. U., Philippou S., Bauer H. D., Breitstadt R., Bruening T., Arch. Toxicol., 75, 625-634 (2002).

4) "JACC Report, Synthetic Amorsphous Silica," European Centre for Ecology and Toxicology of Chemicals, No. 51, 2006.

5) Ferri K. F., Kroemer G., Nat. Cell. Biol., 3, E255-E263 (2001).

6) Ohnishi J., Mizoguchi H., Takeno S., Ikeda M., Mutat. Res., 649, 239-244 (2008) .

7) Damsma G. E., Alt A., Brueckner F., Carell T., Cramer P., Nat. Struct. Mol. Biol., 14, 1127-1133 (2007).

8) Anderson D., Yu T. W., McGregor D. B., Mutagenesis, 13, 539-555 (1998). 